\title{
Analisis Faktor Perilaku Kaitannya dengan Permasalahan Pelayanan Kesehatan Ibu dan Anak (KIA) di Provinsi Riau
}

\author{
Zahtamal $^{1}$, Tuti Restuastuti ${ }^{2}$, Fifia Chandra ${ }^{3}$
}

\begin{abstract}
The low of health community status for this time is still health problems in Indonesia, marked with the high maternal mortality and infant mortality rate. According to health survey, there are still many indicators of maternal, newborn and child health $(\mathrm{MNCH})$, show low achievement. The aim of this study was to find the situation of MNCH services and to describe determining factors of the problems in Riau Province. Method of this research was a descriptive design with quantitative and qualitative data. Result obtained in this research described that some indicators of MNCH services performance were achievable and some were not. The profile of community on health behavior about maternal health was shown with good knowledge, neutral attitude, and good practice. Then, the profile of community health behavior about newborn and child health was shown with middle level of knowledge, positive attitude, and good practice. Key person, mostly categorized as a decision maker for health action was husband/wife. Viewed from quickly action on response of sick/unhealthy family members for $\mathrm{MNCH}$ services indicated that there was not late decision. There were still many communities' beliefs, not match with health value, especially for MNCH.
\end{abstract}

Keywords: MNCH services, health behavior related to $\mathrm{MNCH}$

Masalah kesehatan di Indonesia saat ini adalah masih rendahnya status kesehatan masyarakat, antara lain ditandai dengan tingginya AKI dan AKB. Berdasarkan survei kesehatan dasar 2007, AKI di Indonesia masih berada pada angka 228 per 100.000 kelahiran hidup. Demikian pula AKB, masih berada pada kisaran 26,9 per 1.000 kelahiran hidup. Adapun Departemen Kesehatan Republik Indonesia tahun 2004 menyatakan target yang diharapkan dapat dicapai pada tahun 2010 adalah AKI menjadi 125 per 100.000 kelahiran hidup dan AKB menjadi 15 per 1.000 kelahiran hidup. ${ }^{1}$

Berdasarkan data Dinas Kesehatan Provinsi Riau diketahui angka kematian bayi yaitu 26 per 1000 kelahiran hidup, angka kematian anak balita yaitu 60 per 1000 kelahiran hidup. Pada tahun 2006 jumlah kematian bayi mencapai 1.272 kasus, sedangkan jumlah kematian ibu maternal mencapai

\footnotetext{
1 Penulis untuk korespondensi. Alamat: Bagian Ilmu kesehatan Masyarakat Kedokteran Komunitas Fakultas Kedokteran Universitas Riau Jl. Diponegoro no 1 Pekanbaru, e-mail: tamal75@yahoo.co.id,

${ }^{2,3}$ Bagian Ilmu kesehatan Masyarakat Kedokteran Komunitas Fakultas Kedokteran Universitas Riau
}

179 kasus. $^{2}$ Indikator terkait pelayanan kebidanan juga masih banyak yang belum mencapai target, seperti capaian pertolongan persalinan yang ditolong oleh petugas kesehatan di Provinsi Riau tahun 2008 hanya $74,94 \%$ (target $90 \%$ persalinan). Artinya masih banyak persalinan yang ditolong oleh tenaga non-kesehatan. Tentunya hal ini akan berdampak pada masih tingginya kematian ibu dan kematian bayi. Hal serupa juga didapatkan oleh penelitian Zahtamal, dkk tahun 2006 diketahui bahwa ada lima $(35,7 \%)$ Puskesmas cakupan pertolongan persalinan ditolong petugas kesehatannya di bawah target. Puskesmas yang berada di bawah target tersebut adalah tiga Puskesmas di Kabupaten Kampar (dengan karakteristik wilayah pertanian dan perkebunan) dan dua Puskesmas di Kabupaten Rokan Hilir (dengan karakteristik perairan dan pesisir).

Program kesehatan ibu dan anak (KIA) untuk mengurangi AKI dan AKB telah banyak dilakukan. Program tersebut antara lain "Safe Motherhood program". Program ini di Indonesia dituangkan dalam bentuk program Keluarga Berencana (KB), pelayanan pemeriksaan dan perawatan kehamilan, 
persalinan sehat dan aman serta pelayanan obsetri esensial di pusat layanan kesehatan masyarakat.

Masih tingginya AKI dan AKB di Indonesia termasuk Provinsi Riau disebabkan oleh berbagai faktor, antara lain dari faktor predisposing, faktor pemungkin (enabling) serta faktor pendorong atau penguat (reinforcing). Faktor-faktor tersebut berupa berbagai hambatan antara lain dari aspek geografis, ekonomi, sosiokultural, yang diperberat oleh kelemahan dalam mendeteksi, memutuskan tindakan, merujuk dan keterlambatan dalam menangani keluarga sakit/bermasalah setelah sampai di tempat pelayanan kesehatan komperehensif. Pada kenyataanya belum banyak informasi yang menggambarkan bagaimana situasi faktor-faktor tersebut, terutama aspek perilaku masyarakat. Padahal strategi dan kebijakan yang tepat dengan berdasarkan informasi/bukti sangat diperlukan dalam rangka mengatasi persoalan KIA yang belum optimal. Adapun tujuan yang ingin dicapai dalam penelitian ini adalah diperolehnya gambaran indikator-indikator pelayanan kesehatan yang berkaitan dengan sasaran KIA. Selanjutnya juga diperoleh gambaran beberapa faktor perilaku terkait masalah KIA di masyarakat.

\section{METODE}

Jenis penelitian yang digunakan adalah deskriptif dengan data kuantitatif dan kualitatif. Penelitian ini dilakukan pada empat kabupaten/kota di Provinsi Riau yang bercirikan masyarakat nelayan/pesisir, pertanian/perkebunan, perkotaan dan industri. Representasi dari karakteristik ini maka ditetapkan Kota Pekanbaru (mewakili daerah perkotaan), Kabupaten Kampar (mewakili daerah perkebunan/pertanian), Kota Dumai (mewakili daerah industri) dan kabupaten Rokan Hilir (mewakili daerah nelayan/pesisir). Waktu penelitian dilakukan pada tahun 2009. Subjek penelitian adalah masyarakat di wilayah studi. Jumlah wilayah studi dan responden ditentukan secara Quota Sampling. Besar sampel dalam kajian ini yakni sebanyak 550 orang (setiap kabupaten/kota sekitar $120-150$ orang).

Penentuan sampel menggunakan purposive sampling. Adapun kriteria-kriteria dari subjek penelitian adalah; WUS yang sudah menikah dan memiliki anak, dapat tulis baca dalam bahasa
Indonesia dan bersedia menjadi responden. Instrumen dalam penelitian yang digunakan adalah format identifikasi indikator pelayanan kesehatan dari data sekunder dan kuesioner. Pengelolaan data hasil penelitian dilakukan untuk data kualitatif dan kuantitatif. Pengelolaan secara statistik/kuantitatif berupa distribusi frekuensi masing-masing variabel yang dibantu dengan menggunakan bantuan piranti lunak komputer. Analisis data kualitatif dengan menggunakan analisis isi (content analysis) untuk mendapatkan informasi mendalam tentang variabel yang diteliti dengan cara mencatat, membuat matriks dan analisis secara manual.

\section{HASIL}

\section{Gambaran indikator-indikator pelayanan kesehatan yang berkaitan dengan sasaran ibu dan anak}

Secara umum indikator kerberhasilan pembangunan kesehatan, khususnya untuk pelayanan KIA di wilayah studi sudah mencapai target yang diharapkan. Indikator tersebut antara lain; AKI, jumlah anak balita Bawah Garis Merah (BGM) (kurang 15\%). Beberapa indikator juga menunjukkan indikasi keberhasilan pelayanan kesehatan, walaupun ada kabupaten/kota yang belum mencapai target. Indikator tersebut antara lain; cakupan balita yang naik berat badannya $(\mathrm{N} /$ D) (ada dua kabupaten yang belum mencapai target, yakni Kampar dan Rokan Hilir). Kemudian cakupan Posyandu Purnama (ada satu kabupaten yang belum mencapai target, yakni Rokan Hilir). Selanjutnya cakupan kunjungan bayi (ada dua kabupaten yang belum mencapai target, yakni Kampar dan Rokan Hilir). Indikator yang belum mencapai target antara lain: cakupan kunjungan ibu hamil (K4), pertolongan persalinan ditolong petugas kesehatan, kunjungan neonatus (KN-2), cakupan peserta $\mathrm{KB}$ aktif, cakupan Desa/Kelurahan yang kategori Universal Child Immunization (UCI), cakupan anak balita yang mendapat kapsul vitamin A 2x/tahun, cakupan ibu hamil yang mendapat 90 tablet fe, cakupan pemberian MP-ASI pada anak balita BGM dari keluarga miskin, cakupan rumah tangga sehat, cakupan bayi yang mendapat ASI Ekslusif. 


\section{Gambaran Faktor-faktor perilaku yang berhubungan dengan pelayanan KIA}

Jumlah responden dalam penelitian ini adalah 550 orang dengan rata-rata umur 29,63 tahun (Standar Deviasi/SD; 5,82). Status ekonomi responden sebagian besar berpenghasilan 800.000-2.000.000 (menengah rendah) yakni $61,3 \%$. Selanjutnya jika dilihat dari cara pembayaran untuk mendapatkan pelayanan kesehatan yang sering digunakan keluarga adalah bayar langsung, yakni 397 orang $(72,2 \%)$. Hanya $20,1 \%$ yang ditanggung oleh Asuransi (PT. Askes/Jamsostek, Askes swasta dan Jamkesmas). Tenaga penolong dalam pemenuhan kebutuhan pelayanan kesehatan keluarga sebagian besar adalah tenaga kesehatan (dokter/ perawat/bidan/mantri kesehatan), yakni 542 orang $(98,5 \%)$. Sarana/fasilitas kesehatan yang paling sering digunakan oleh keluarga, sebagian besar responden menjawab Puskesmas yakni 266 orang $(48,4 \%)$.
1) Gambaran pengetahuan responden tentang kehamilan, persalinan dan nifas

Gambaran rata-rata skor pengetahuan responden tentang kehamilan, persalinan dan nifas adalah 74,05 (SD: 14,51). Secara keseluruhan diketahui kategori pengetahuan responden berada pada kategori baik yakni 366 orang $(66,6 \%)$. Hal ini dapat dilihat pada Tabel 1. Jumlah yang paling banyak kategori baiknya adalah Kota Dumai yakni sebanyak $86,2 \%$, sedangkan yang terendah adalah kabupaten Rokan Hilir yaitu hanya 50,7\%. Berdasarkan uji komparatif kategorik diketahui bahwa terdapat perbedaan yang bermakna pengetahuan responden dengan nilai signifikan $(p$ value; 0,000 ). Gambaran kategori pengetahuan per kabupaten/kota seperti tabel berikut ini:

Tabel 1. Distribusi frekuensi kategori pengetahuan responden tentang kehamilan, persalinan dan nifas berdasarkan kabupaten/kota

\begin{tabular}{|c|c|c|c|c|c|c|}
\hline \multirow{2}{*}{\multicolumn{2}{|c|}{$\begin{array}{l}\text { Kategori pengetahuan tentang } \\
\text { kesehatan ibu }\end{array}$}} & \multicolumn{4}{|c|}{ Kabupaten } & \multirow[b]{2}{*}{ Total } \\
\hline & & Rokan Hilir & Dumai & Pekanbaru & Kampar & \\
\hline \multirow[t]{3}{*}{ kurang } & Jumlah & 3 & 0 & 0 & 2 & 5 \\
\hline & Nilai Expected & 1.3 & 1.3 & 1.1 & 1.4 & 5.0 \\
\hline & $\%$ Kabupaten & $2.1 \%$ & $.0 \%$ & $.0 \%$ & $1.3 \%$ & $.9 \%$ \\
\hline \multirow[t]{3}{*}{ cukup } & Jumlah & 67 & 19 & 28 & 65 & 179 \\
\hline & Nilai Expected & 46.2 & 44.9 & 37.8 & 50.1 & 179.0 \\
\hline & $\%$ Kabupaten & $47.2 \%$ & $13.8 \%$ & $24.1 \%$ & $42.2 \%$ & $32.5 \%$ \\
\hline \multirow[t]{3}{*}{ baik } & Jumlah & 72 & 119 & 88 & 87 & 366 \\
\hline & Nilai Expected & 94.5 & 91.8 & 77.2 & 102.5 & 366.0 \\
\hline & $\%$ within Kabupaten & $50.7 \%$ & $86.2 \%$ & $75.9 \%$ & $56.5 \%$ & $66.5 \%$ \\
\hline \multirow[t]{3}{*}{ Total } & Jumlah & 142 & 138 & 116 & 154 & 550 \\
\hline & Nilai Expected & 142.0 & 138.0 & 116.0 & 154.0 & 550.0 \\
\hline & $\%$ Kabupaten & $100.0 \%$ & $100.0 \%$ & $100.0 \%$ & $100.0 \%$ & $100.0 \%$ \\
\hline
\end{tabular}

2) Gambaran pengetahuan responden tentang kesehatan bayi

Berdasarkan pengolahan data didapatkan ratarata skor pengetahuan responden tentang kesehatan bayi adalah 63,87 (SD: 19,01). Secara keseluruhan diketahui bahwa kategori pengetahuan responden berada pada kategori cukup yakni 283 orang $(51,5 \%)$. Gambaran kategori pengetahuan per kabupaten/kota diperoleh seperti tabel berikut ini: 
Tabel 2. Distribusi frekuensi kategori pengetahuan responden tentang kesehatan bayi berdasarkan kabupaten/kota

\begin{tabular}{|c|c|c|c|c|c|c|}
\hline \multirow{2}{*}{\multicolumn{2}{|c|}{$\begin{array}{l}\text { Kategori pengetahuan } \\
\text { tentang kesehatan bayi }\end{array}$}} & \multicolumn{4}{|c|}{ Kabupaten } & \multirow[b]{2}{*}{ Total } \\
\hline & & Rokan & Dumai & Pekanbanu & Kampar & \\
\hline \multirow[t]{3}{*}{ kurang } & Jumlah & 15 & 5 & 3 & 4 & 27 \\
\hline & Nilai Expected & 7.0 & 6.8 & 5.7 & 7.6 & 27.0 \\
\hline & $\%$ Kabupaten & $10.6 \%$ & $3.6 \%$ & $2.6 \%$ & $2.6 \%$ & $4.9 \%$ \\
\hline \multirow[t]{3}{*}{ cukup } & Jumlah & 69 & 86 & 43 & 85 & 283 \\
\hline & Nilai Expected & 73.1 & 71.0 & 59.7 & 79.2 & 283.0 \\
\hline & $\%$ Kabupaten & $48.6 \%$ & $62.3 \%$ & $37.1 \%$ & $55.2 \%$ & $51.5 \%$ \\
\hline \multirow[t]{3}{*}{ baik } & Jumlah & 58 & 47 & 70 & 65 & 240 \\
\hline & Nilai Expected & 62.0 & 60.2 & 50.6 & 67.2 & 240.0 \\
\hline & $\%$ Kabupaten & $40.8 \%$ & $34.1 \%$ & $60.3 \%$ & $42.2 \%$ & $43.6 \%$ \\
\hline \multirow[t]{3}{*}{ Total } & Jumlah & 142 & 138 & 116 & 154 & 550 \\
\hline & Nilai Expected & 142.0 & 138.0 & 116.0 & 154.0 & 550.0 \\
\hline & $\%$ Kabupaten & $100.0 \%$ & $100.0 \%$ & $100.0 \%$ & $100.0 \%$ & $100.0 \%$ \\
\hline
\end{tabular}

Berdasarkan Tabel 2 di atas diketahui bahwa kategori pengetahuan responden sedikit bervariasi, di mana tiga kabupaten/kota sebagian besar dengan kategori cukup (Rokan Hilir, Dumai dan Kampar), sedangkan Pekanbaru sebagian besar $(60,3 \%)$ berada pada kategori baik. Selanjutnya kabupaten yang kurang ideal kategori pengetahuannya adalah Rokan Hilir, di mana kategori cukup dan kurangnya masih banyak yakni masing-masing $48.6 \%$ dan 10,6\%. Melalui uji Chi-square diketahui bahwa terdapat perbedaan yang bermakna pengetahuan antar kabupaten/kota dengan nilai signifikan ( $p$ value; 0,000$)$.

3) Gambaran sikap responden terhadap kehamilan, persalinan dan nifas

Secara keseluruhan diketahui bahwa rerata skor sikap responden terhadap kehamilan, persalinan dan nifas adalah 69,92 (SD; 11,59). Adapun kategori sikap responden sebagian besar berada pada kategori netral yakni 137 responden $(93,8 \%)$. Hal ini dapat dilihat pada Tabel 3 berikut:

Tabel 3. Distribusi frekuensi kategori sikap responden terhadap kehamilan, persalinan dan nifas berdasarkan kabupaten/kota

\begin{tabular}{|c|c|c|c|c|c|c|}
\hline \multicolumn{2}{|c|}{ Katogori sikap } & \multicolumn{4}{|c|}{ Kabupaten } & \multirow[b]{2}{*}{ Total } \\
\hline & & $\begin{array}{l}\text { Rokan } \\
\text { Hilir }\end{array}$ & Dumai & Pekanbaru & Kampar & \\
\hline \multirow[t]{3}{*}{ Netral } & Jumlah & 74 & 59 & 31 & 60 & 224 \\
\hline & Nilai Expected & 57.8 & 56.2 & 47.2 & 62.7 & 224.0 \\
\hline & $\%$ Kabupaten & $52.1 \%$ & $42.8 \%$ & $26.7 \%$ & $39.0 \%$ & $40.7 \%$ \\
\hline \multirow[t]{3}{*}{ Positif } & Jumlah & 68 & 79 & 85 & 94 & 326 \\
\hline & Nilai Expected & 84.2 & 81.8 & 68.8 & 91.3 & 326.0 \\
\hline & $\%$ Kabupaten & $47.9 \%$ & $57.2 \%$ & $73.3 \%$ & $61.0 \%$ & $59.3 \%$ \\
\hline \multirow[t]{3}{*}{ Total } & Jumlah & 142 & 138 & 116 & 154 & 550 \\
\hline & Nilai Expected & 142.0 & 138.0 & 116.0 & 154.0 & 550.0 \\
\hline & $\%$ Kabupaten & $100 \%$ & $100 \%$ & $100 \%$ & $100 \%$ & $100 \%$ \\
\hline
\end{tabular}


Berdasarkan Tabel 3 di atas diketahui bahwa kategori sikap responden sedikit bervariasi, di mana 3 kabupaten sebagian besar dengan kategori positif (Dumai, Pekanbaru dan Kampar), sedangkan Rokan Hilir sebagian besar adalah netral yakni sebanyak $52.1 \%$. Melalui uji Chi-square diketahui bahwa terdapat perbedaan yang bermakna kategori sikap antar kabupaten/kota dengan nilai signifikan ( $p$ value; 0,001).
4) Gambaran sikap responden terhadap kesehatan bayi

Secara keseluruhan diketahui bahwa rerata skor sikap responden terhadap kesehatan bayi adalah 75,47 (SD: 15,06). Adapun kategori sikap responden sebagian besar sudah berada pada kategori positif yakni 362 responden $(65,8 \%)$. Gambaran kategori sikap per kabupaten/kota seperti pada tabel berikut ini:

Tabel 4. Distribusi frekuensi kategori sikap responden terhadap kesehatan bayi berdasarkan kabupaten/ kota

\begin{tabular}{|c|c|c|c|c|c|c|}
\hline \multirow{2}{*}{\multicolumn{2}{|c|}{ Katogori sikap }} & \multirow{2}{*}{$\begin{array}{l}\text { Rokan } \\
\text { Hilir }\end{array}$} & \multirow{2}{*}{\multicolumn{2}{|c|}{ Kabupaten }} & \multirow{2}{*}{ Kampar } & \multirow{2}{*}{ Total } \\
\hline & & & & & & \\
\hline \multirow{3}{*}{ Negatif } & Jumlah & 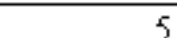 & 0 & 0 & 0 & 5 \\
\hline & Nilai Expected & 1.3 & 1.3 & 1.1 & 1.4 & 5.0 \\
\hline & $\%$ Kabupaten & $3.5 \%$ & $.0 \%$ & $.0 \%$ & $.0 \%$ & $.9 \%$ \\
\hline \multirow[t]{3}{*}{ Netral } & Jumlah & 65 & 47 & 19 & 52 & 183 \\
\hline & Nilai Expected & 47.2 & 45.9 & 38.6 & 51.2 & 183.0 \\
\hline & $\%$ Kabupaten & $45.8 \%$ & $34.1 \%$ & $16.4 \%$ & $33.8 \%$ & $33.3 \%$ \\
\hline \multirow[t]{3}{*}{ Positif } & Jumlah & 72 & 91 & 97 & 102 & 362 \\
\hline & Nilai Expected & 93.5 & 90.8 & 76.3 & 101.4 & 362.0 \\
\hline & $\%$ Kabupaten & $50.7 \%$ & $65.9 \%$ & $83.6 \%$ & $66.2 \%$ & $65.8 \%$ \\
\hline \multirow[t]{3}{*}{ Total } & Jumlah & 142 & 138 & 116 & 154 & 550 \\
\hline & Nilai Expected & 142.0 & 138.0 & 116.0 & 154.0 & 550.0 \\
\hline & $\%$ Kabupaten & $100 \%$ & $100 \%$ & $100 \%$ & $100 \%$ & $100 \%$ \\
\hline
\end{tabular}

Berdasarkan Tabel 4 di atas diketahui bahwa kategori sikap responden sedikit bervariasi, di mana tiga kabupaten/kota sebagian besar dengan kategori positif (Dumai, Pekanbaru dan Kampar), sedangkan Rokan Hilir sebagian besar adalah netral yakni sebanyak $52.1 \%$. Melalui analisis statistik dengan uji komparatif kategorik tidak berpasangan diketahui bahwa terdapat perbedaan yang bermakna kategori sikap antar kabupaten/kota dengan nilai signifikan ( $p$ value; 0,000 ).
5) Gambaran praktek/tindakan responden untuk peningkatan dan pemeliharaan kesehatan ibu hamil, ibu bersalin dan ibu nifas

Secara keseluruhan diketahui bahwa rerata skor praktek responden untuk peningkatan dan pemeliharaan kesehatan ibu hamil, ibu bersalin dan ibu nifas adalah 80,70 (SD;18,03). Adapun kategori praktek responden sebagian besar berada pada kategori baik yakni sebanyak 329 responden (59,8\%). Gambaran kategori praktek per kabupaten/ kota seperti pada tabel berikut ini: 
Tabel 5. Distribusi frekuensi kategori praktek responden untuk peningkatan dan pemeliharaan kesehatan ibu hamil, ibu bersalin dan ibu nifas berdasarkan kabupaten/kota

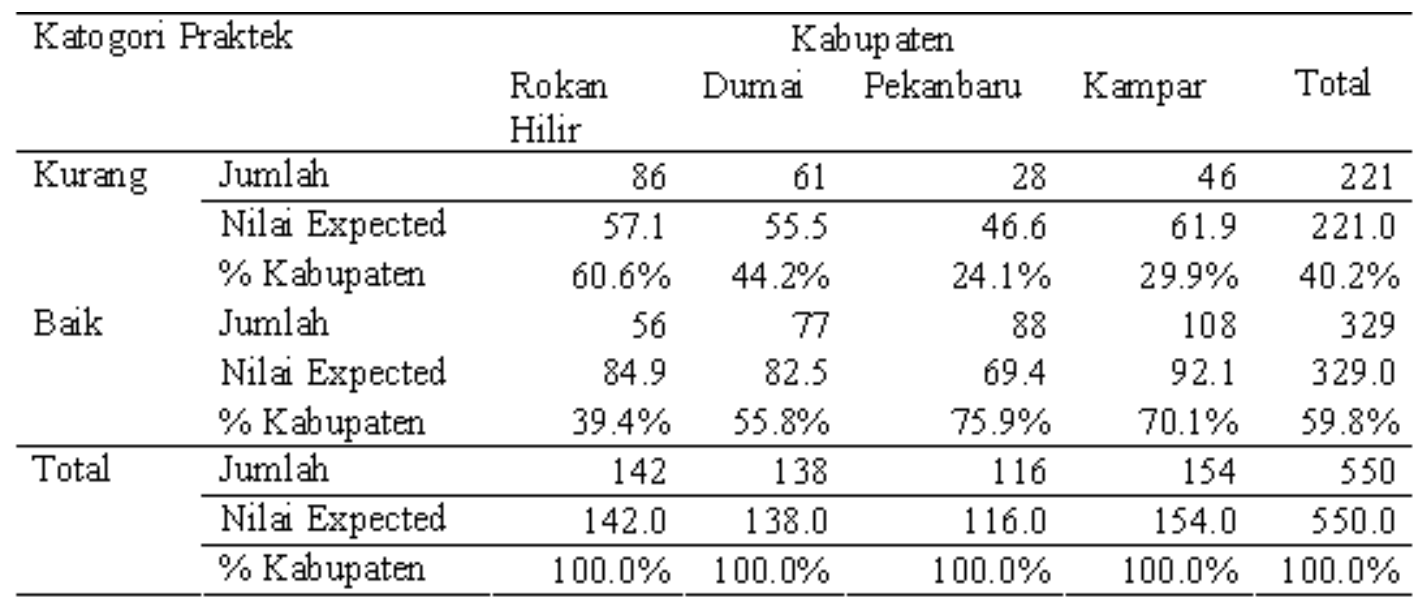

Berdasarkan Tabel 5 diketahui bahwa kategori praktek responden sedikit bervariasi, di mana 3 kabupaten sebagian besar dengan kategori baik (Dumai, Pekanbaru dan Kampar), sedangkan Rokan Hilir sebagian besar berada pada kategori kurang yakni sebanyak $60,6 \%$. Melalui uji Chi-square diketahui bahwa terdapat perbedaan yang bermakna kategori praktek antar kabupaten/kota dengan nilai signifikan ( $p$ value; 0,000$)$.
6) Gambaran praktek/tindakan upaya peningkatan kesehatan pada bayi dan anak balita

Secara keseluruhan diketahui bahwa rerata skor praktek upaya peningkatan kesehatan pada bayi dan anak balita adalah 84,89 (SD; 17,19). Adapun kategori praktek responden sebagian besar berada pada kategori baik yakni sebanyak 446 responden $(81,1 \%)$.

Tabel 6. Distribusi frekuensi kategori praktek responden untuk peningkatan kesehatan pada bayi dan anak balita berdasarkan kabupaten/kota

\begin{tabular}{|c|c|c|c|c|c|c|}
\hline \multicolumn{2}{|c|}{ Katogori Praktek } & \multicolumn{4}{|c|}{ Kabupaten } & \multirow[b]{2}{*}{ Total } \\
\hline & & $\begin{array}{l}\text { Rokan } \\
\text { Hilir }\end{array}$ & Dumai & Pekanbaru & Kampar & \\
\hline \multirow[t]{3}{*}{ Kurang } & Jumlah & 52 & 20 & 5 & 27 & 104 \\
\hline & Nilai Expected & 26.9 & 26.1 & 21.9 & 29.1 & 104.0 \\
\hline & $\%$ Kabupaten & $36.6 \%$ & $14.5 \%$ & $4.3 \%$ & $17.5 \%$ & $18.9 \%$ \\
\hline \multirow[t]{3}{*}{ Baik } & Jumlah & 90 & 118 & 111 & 127 & 446 \\
\hline & Nilai Expected & 115.1 & 111.9 & 94.1 & 124.9 & 446.0 \\
\hline & $\%$ Kabupaten & $63.4 \%$ & $85.5 \%$ & $95.7 \%$ & $82.5 \%$ & $81.1 \%$ \\
\hline \multirow[t]{3}{*}{ Total } & Jumlah & 142 & 138 & 116 & 154 & 550 \\
\hline & Nilai Expected & 142.0 & 138.0 & 116.0 & 154.0 & 550.0 \\
\hline & $\%$ Kabupaten & $100.0 \%$ & $100.0 \%$ & $100.0 \%$ & $100.0 \%$ & $100.0 \%$ \\
\hline
\end{tabular}

Berdasarkan tabel 6 diketahui bahwa kategori praktek responden antar kabupaten/kota adalah sama, di mana 4 kabupaten/kota sebagian besar dengan kategori baik. Akan tetapi Kabupaten Rokan
Hilir kategori kurangnya masih cukup banyak yakni sebanyak $36,6 \%$. Kabupaten/kota yang sangat baik praktek untuk peningkatan kesehatan pada bayi dan anak balitanya adalah kota Pekanbaru, dengan 
kategori baiknya sebanyak 95,7\%. Melalui uji Chisquare diketahui bahwa terdapat perbedaan yang bermakna kategori praktek antar kabupaten/kota dengan nilai signifikan ( $p$ value; 0,000 ).

7) Gambaran faktor sosiokultural yang berhubungan dengan pelayanan KIA

Kategori siapakah orang kunci yang berpengaruh besar terhadap pengambilan keputusan dalam upaya tindakan kesehatan sebagian besar adalah suami/isteri, yakni sebanyak 513 responden $(93,3 \%)$. Selanjutnya dari aspek kecepat-tanggapan keluarga dalam merespon anggota keluarga yang sakit (bermasalah) terutama terhadap KIA sebagian besar (458 orang/83,3\%) menjawab tidak ada keterlambatan dalam memutuskan upaya tindakan kesehatan. Jika dilihat berasarkan kabupaten/kota diketahui bahwa responden masih banyak juga yang mengatakan "Ya/terlambat" yakni Kota Pekanbaru sebanyak 20,7\% dan Rokan Hilir 20,4\%. Khususnya untuk kecepat-tanggapan keluarga dalam merespon anggota keluarga aspek "keterlambatan dalam memutuskan upaya tindakan untuk ibu yang mau bersalin" sebagian besar (495 orang/90,0\%) menjawab tidak. Berdasarkan kabupaten/kota diketahui bahwa responden masih banyak yang mengatakan "Ya/terlambat" yakni Rokan Hilir 15,5\% dan Kota Pekanbaru sebanyak 12,1\%.

Berasarkan pengolahan data diketahui bahwa masih banyak kepercayaan masyarakat yang belum sesuai dengan nilai-nilai kesehatan, terutama terhadap aspek KIA. Dari 274 responden yang menjawab pernyataan kebiasaan/tradisi yang diterapkan /dipercayai dalam kesehariannya yang berhubungan dengan kesehatan ibu hamil/bersalin /nifas/menyusui didapatkan bahwa 124 (45,26\%) yang memiliki kepercayaan yang tidak sesuai dengan nilai-nilai kesehatan. Adapun jenis kepercayaan yang keliru/tidak sesuai tersebut sebagian besar adalah terkait aspek gizi selama hamil/bersalin/nifas dan menyusui, yakni 31,32\%. Kepercayaan yang keliru tersebut misalnya adalah; selama bersalin tidak boleh memakan udang, selama menyusui tidak boleh makan kerang. Ada juga yang mempercayai bahwa selama nifas tidak boleh minum air putih, makan ikan dan buah buahan. Selain itu ada juga aspek kepercayaan yang keliru ketika hamil $(29,52 \%)$. Contoh kepercayaan yang keliru tersebut antara lain; urut (kusuk) ibu ketika hamil ke dukun. Jika dilihat per kabupaten/kota, responden yang memiliki kepercayaan yang belum sesuai tersebut Kabupaten Rokan Hilir adalah 64,47\%; Kabupaten Kampar 46,55\%; Kota Pekanbaru 38,70\% dan Kota Dumai $30,77 \%$. Aspek kepercayaan yang keliru tersebut sebagian besar juga terkait aspek gizi selama hamil/bersalin/nifas dan menyusui.

Selanjutnya dari 254 orang yang menjawab pernyataan kebiasaan/tradisi yang diterapkan/ dipercayai dalam keseharian responden yang berhubungan dengan kesehatan bayi dan anak balita didapatkan bahwa ada $60(23,62 \%)$ memiliki kepercayaan yang tidak sesuai dengan nilai-nilai kesehatan. Adapun jenis kepercayaan yang tidak sesuai tersebut sebagian besar terkait aspek gizi pada bayi dan balita atau tidak mendukung ASI ekslusif, yakni $42,62 \%$. Kepercayaan tersebut misalnya adalah; bayi baru lahir dikasih kelapa muda, setiap bayi baru lahir di beri makan pisang. Selain itu juga aspek kepercayaan yang keliru terhadap penanganan kesehatan pada bayi dan anak balita $(27,87 \%)$. Contoh kepercayaan yang keliru tersebut antara lain; kepercayaan ke dukun (diberi "tetomeh" sejenis ramuan yang dipercaya dapat menyembuhkan penyakit/mengusir roh jahat penyebab penyakit).

\section{PEMBAHASAN}

Jika dilihat dari 14 indikator yang dinilai, terlihat hanya empat indikator $(28,7 \%)$ yang sudah mencapai target. Hal ini menunjukkan bahwa pembangunan kesehatan atau pelayanan kesehatan yang harus diberikan kepada masyarakat belum maksimal. Dampak dari hal ini tentunya akan sulit untuk mencapai derajat kesehatan yang optimal. Hasil penelitian ini tidak jauh berbeda dengan penelitian Zahtamal,dkk di daerah yang sama pada tahun 2006. Artinya pembangunan kesehatan di Provinsi Riau selama dua tahun terakhir belum menunjukkan perubahan yang signifikan terhadap indikator SPMnya. ${ }^{3}$

Hasil ini juga tidak jauh berbeda dengan capaian untuk beberapa kabupaten/kota di Indonesia. Misalnya Indikator SPM bidang kesehatan yang diperoleh oleh Kabupaten Polewali Mandar Sulawesi Barat dimana cakupan ANC K4nya masih kurang dari target nasional yakni $72,3 \%$. ${ }^{4}$ Hal yang sama juga ditunjukkan oleh capaian 
Kabupaten Ngawi, 2008, dimana untuk target Posyandu Purnama hanya 286 (24,57\%), selain itu juga untuk persentase cakupan pelayanan K4 yang hanya sebesar $13.218(94,49 \%)$. Selanjutnya beberapa indikator untuk kesehatan bayi dan anak balita seperti cakupan pemberian kapsul vitamin A 2 kali pada balita pada tahun 2008 , hanya sebanyak $35.268(78,00 \%) .^{5}$

Kategori pengetahuan responden secara keseluruhan tentang kesehatan maternal berada pada kategori baik. Hal ini tentunya akan mendukung terbentuknya perilaku yang baik atau upaya untuk memodifikasi perilaku yang dilakukan pihak terkait, misalnya oleh tenaga kesehatan akan lebih mudah. Pengetahuan baik merupakan modal awal untuk praktek yang baik. Pada akhirnya akan terjadi penurunan masalah maternal atau akan meningkatnya indikator pelayanan kesehatan di masyarakat. ${ }^{6}$

Selanjutnya diketahui bahwa pengetahuan responden tentang kesehatan bayi dan anak balita berada pada kategori cukup. Banyaknya responden yang memiliki pengetahuan "cukup" ini tentunya merupakan suatu yang belum ideal. Hal ini akan berdampak terhadap sulitnya upaya modifikasi perilaku yang akan dilakukan oleh pihak terkait, misalnya oleh tenaga kesehatan, baik dalam hal membentuk perilaku baru, meningkatkan perilaku maupun mempertahankan perilaku. Belum idealnya pengetahuan merupakan salah satu penyebab tingginya atau meningkatnya kasus/permasalahan kesehatan yang terjadi di masyarakat. Seseorang yang belum memiliki pengetahuan yang baik, akan sulit melakukan perubahan perilaku ke arah yang lebih baik atau akan sulit menerima perilaku yang lebih baik tersebut, sebaliknya orang yang telah memiliki pengetahuan yang cukup baik, akan menerima atau mengadopsi perilaku baru dengan baik pula. ${ }^{6}$

Kategori sikap responden terhadap kesehatan ibu maternal sebagian besar adalah netral. Sikap netral dapat dikatakan sebagai sikap yang belum ideal, mengingat sewaktu-waktu dapat berubah ke arah sikap positif maupun negatif. Faktor yang mempengaruhi pembentukan sikap seseorang dan hubungannya dengan objek-objek tertentu dalam berinteraksi sosial saling mempengaruhi perilaku individu tersebut sebagai anggota masyarakat.
Individu bereaksi membentuk sikap tertentu terhadap objek psikologis yang dihadapinya. Kurangnya stimulasi positif menimbulkan hanya sebagian kecil orang yang punya pengetahuan tentang objek tertentu. Selanjutnya rangsangan positif yang kurang juga akan berpengaruh terhadap bertahannya kondisi sikap yang netral, malah dapat menjadi sikap yang negatif. ${ }^{7}$

Kategori praktek responden terhadap kesehatan maternal sebagian besar adalah baik. Kategori praktek ini walaupun lebih 50\% baik, namun angka ini tentunya masih belum ideal. Karena ada sebanyak 40,2\% responden belum melakukan upaya yang mendukung kesehatan maternal. Banyak faktor yang terkait kenapa masyarakat belum melakukan praktek kesehatan dengan baik. Berdasarkan hasil penelitian diketahui faktor tersebut antara adalah predisposing factors, enabling factors dan reinforcing factors. ${ }^{5}$ Beberapa fakta yang ditemukan dalam penelitian ini adalah bahwa orang dengan tingkat penghasilan belum ideal, cenderung prakteknya masih kurang. Penelitian ini menemukan bahwa dari semua responden yang berpengatahuan kurang, sebagian besar berasal dari responden yang berpenghasilan Rp. 800.000-2.000.000.

Fakta lain ditemukan bahwa masyarakat yang belum tercover oleh asuransi (askes/asuransi swasta/ jamsostek/jamkesmas), praktek mereka sebagian besar adalah kurang. Hasil dalam penelitian ini menunjukkan bahwa masyarakat miskin sebagian besar mereka sudah tercover asuransi (terutama Jamkesmas), dan terbukti praktek mereka sebagian besar adalah kategori baik. Masyarakat ekonomi menengah-atas dan ekonomi baik juga cenderung praktek mereka baik. Kontras dengan mereka yang berpenghasilan menengah bawah sebagian besar mereka belum tercover asuransi, terbukti sebagian besar mereka dengan kategori praktek kurang. Oleh karena itu dalam penelitian ini diharapkan pemerintah tidak hanya konsentrasi menjamin pembiayaan kesehatan pada masyarakat miskin saja. Walaupun secara implementasi mereka dengan kategori penghasilan menengah ke atas tidak mendapat jaminan pembiayaan kesehatan dari subsidi pemerintah, hendaknya kepada mereka ditanamkan supaya ikut dalam kepesertaan asuransi kesehatan secara mandiri (termasuk menghidupkan kembali dana sehat), terutama bagi mereka yang berpenghasilan menengah-rendah, karena 
masyarakat ekonomi tinggi mungkin mereka mampu membiayai sendiri.

Praktek responden untuk peningkatan kesehatan bayi dan anak balita sebagian besar berada pada kategori baik. Pernyataan praktek yang paling banyak "tidak dilakukan" oleh responden adalah mengenai selalu memberikan ASI jolong untuk bayi. Hal ini menunjukkan pengetahuan masyarakat tentang ASI secara umum masih kurang. Penelitian lain menunjukan bahwa mereka tidak tahu melakukan, dan mereka tahu tetapi tidak melakukan, termasuk peran petugas kesehatan. Terkait dengan ASI ekslusif, ditemukan juga bahwa bidan menyatakan setuju memberikan susu formula kepada bayi baru lahir dan sebagian dari ibu-ibu dianjurkan oleh petugas kesehatan untuk memberi susu formula pada minggu pertama setelah kelahiran. $^{8}$

Hasil penelitian menunjukkan bahwa orang kunci yang berpengaruh besar terhadap pengambilan keputusan dalam tindakan kesehatan sebagian besar adalah suami/isteri. Hasil yang sama juga ditunjukkan oleh penelitian di NTT diketahui bahwa pengambil keputusan di keluarga untuk pencarian pertolongan persalinan adalah $36,7 \%$ isteri, $30,7 \%$ suami. ${ }^{9}$ Selanjutnya jika dilihat dari aspek kecepattanggapan keluarga dalam merespon anggota keluarga yang sakit terutama terhadap KIA diketahui bahwa sebagian besar responden marasa tidak ada keterlambatan dalam memutuskan upaya tindakan kesehatan. Begitu juga untuk kecepat-tanggapan keluarga dalam merespon atau memutuskan upaya tindakan untuk ibu yang mau bersalin sebagian besar responden menjawab tidak. Untuk ke dua aspek ini, jika dilihat berasarkan kabupaten/kota diketahui bahwa responden Kota Pekanbaru masih banyak yang mengatakan "terlambat". Hal ini mungkin disebabkan karena masyarakat berusaha mencoba mengobati sendiri terlebih dahulu anggota keluarga yang sakit berdasarkan pengetahuan mereka. Ditambah lagi dengan banyaknya tersedia toko obat/ apotik di Kota Pekanbaru.

Berdasarkan pengolahan data diketahui bahwa masih banyak kepercayaan masyarakat yang belum sesuai dengan nilai-nilai kesehatan, terutama terhadap aspek KIA. Jenis kepercayaan yang keliru/ tidak sesuai tersebut sebagian besar adalah terkait aspek gizi selama hamil/bersalin/nifas dan menyusui. Menurut asumsi mereka ketika melakukan hal tersebut maka tubuh mereka akan gatal karena makan udang atau kerang, akan semakin banyak perdarahan jika mereka makan ikan pada masa nifas. Hal ini tentunya akan menyebabkan si ibu menjadi banyak pantangan makan terhadap makanan tersebut. Padahal jika dilihat dari kandungan gizi, makanan tersebut akan sangat bermanfaat bagi ibu dan bayinya. Makanan laut seperti kerang dan udang mengandung beberapa zat gizi penting, yang merupakan sumber protein hewani dan bahkan digolongkan kepada "complete protein" karena kadar asam amino esensialnya tinggi dan sekitar 85-95\% mudah diserap tubuh. Sedangkan ikan juga merupakan sumber protein tinggi yang sangat dibutuhkan tubuh. Hal ini tentu saja berdampak buruk bagi kesehatan ibu dan janin, karena si ibu akan kekurangan asupan protein yang penting bagi tubuh yang tentunya akan berpengaruh juga bagi perkembangan janin atau bayinya. ${ }^{10}$

Selanjutnya ditemukan juga masih banyak kebiasaan/tradisi yang diterapkan/dipercayai responden yang berhubungan dengan kesehatan bayi dan anak balita tidak sesuai dengan nilai-nilai kesehatan. Adapun jenis kepercayaan tersebut sebagian besar terkait aspek gizi pada bayi dan anak balita atau tidak mendukung ASI ekslusif serta penanganan kesehatan bayi dan anak balita. Menurut asumsi/kepercayaan mereka ketika bayi hanya diberi ASI tidak akan membuat bayi mereka kenyang, dan akan kekurangan gizi. Padahal, pemberian makanan dan cairan dapat menjadi sarana masuknya bakteri patogen, yang mana bayi usia dini rentan terhadap bakteri penyebab diare, terutama yang hidup di lingkungan yang kurang higienis dan sanitasi buruk. Mengganti ASI dengan cairan yang tidak bergizi akan berdampak buruk bagi kondisi bayi, daya tahan hidup, pertumbuhan, dan perkembangannya. Konsumsi air putih atau cairan lain meskipun dalam jumlah sedikit akan membuat bayi merasa kenyang, sehingga tidak mau menyusu, padahal ASI kaya dengan gizi yang sempurna untuk bayi. Penelitian menunjukkan bahwa memberi air putih sebagai tambahan cairan sebelum bayi berusia 6 bulan dapat mengurangi asupan ASI hingga 11\%. Pemberian air manis dalam minggu pertama usia bayi berhubungan dengan penurunan berat badan bayi. ${ }^{11}$ 


\section{KESIMPULAN}

Berdasarkan hasil penelitian diketahui bahwa gambaran perilaku responden tentang kehamilan, persalinan dan nifas yakni dengan kategori pengetahuan baik, kategori sikap yang netral dan kategori praktek sebagian besar adalah baik. Perilaku responden terhadap kesehatan bayi dan anak balita sebagian besar kategori pengetahuan adalah cukup, sikap sudah berada pada kategori positif dan praktek pada kategori baik. Kategori orang kunci yang berpengaruh besar terhadap pengambilan keputusan dalam upaya tindakan kesehatan sebagian besar adalah suami/isteri. Selanjutnya jika dilihat dari aspek kecepattanggapan keluarga dalam merespon anggota keluarga yang sakit (bermasalah) terutama terhadap KIA diketahui bahwa sebagian besar responden tidak marasa ada keterlambatan dalam memutuskan upaya tindakan kesehatan. Diketahui juga bahwa masih banyak kepercayaan masyarakat yang belum sesuai dengan nilai-nilai kesehatan, terutama terhadap aspek KIA

\section{UCAPAN TERIMA KASIH}

Penulis mengucapkan terima kasih kepada pemerintah Provinsi Riau dalam hal ini kepada Kepala Dinas Kesehatan Provinsi Riau, Kepala Dinas Kesehatan Kota Pekanbaru dan jajarannya, Kepala Dinas Kesehatan Kota Dumai dan jajarannya, Kepala Dinas Kesehatan Kabupaten Rokan Hilir dan jajarannya, Kepala Dinas Kesehatan Kabupaten Kampar dan jajarannya, serta masyarakat yang menjadi responden atas kerjasama yang diberikan selama penilitian ini berlangsung.

\section{DAFTAR PUSTAKA}

1. Departemen Kesehatan RI. Setiap Jam 2 Orang Ibu Bersalin Meninggal Dunia, Depkes RI, Jakarta. Tersedia di http://202.155.5.44 / index.php?option $=$ news $\&$ task $=$ viewarticle $\&$ $\operatorname{sid}=448 \&$ Itemid $=2$. (diakses tanggal 2 Januari 2008). 2004.
2. Dinas Kesehatan Provinsi Riau. Profil Kesehatan Provinsi Riau tahun 2007, Provinsi Riau. 2007

3. Zahtamal, dkk. Study/Survey MMR-IMR dan Indikator-Indikator Derajat Kesehatan Tahun 2007. PT. Wastu Asrindoriau. Riau. 2007.

4. Arali. Capaian MDGs Peningkatan Kesehatan Ibu di Polewali Mandar. Tersedia di: http:// arali2008.wordpress.com/2009/08/09/capaianmdgs-peningkatan-kesehatan-ibu-di-polewalimandar. (diakses 2 November 2009). 2008.

5. Dinas Kesehatan Kabupaten Ngawi. Profil Kesehatan Kabupaten Ngawi, 2008. Tersedia di: www.profilkesngawi2008.html. (diakses 2 November 2009). 2009

6. Notoatmodjo, S. Promosi kesehatan - Teori dan Aplikasi, Jakarta : PT Rineka Cipta. 2005.

7. Azwar, S. Sikap Manusia, Teori Dan Pengukurannya. Yogyakarta: Pustaka Pelajar Offset. 2000.

8. Meyske, E. Faktoryang berkaitan dengan praktek pemberian ASI ekslusif. Tersedia di: http:// www.fkm.unair.ac.id. (diakses 2 November 2009). 2009.

9. Musadad A, Rachmalina, Rahajeng E. Pengambilan keputusan dalam pertolongan persalinan di Provinsi Nusa Tenggara Timur. Tersedia di: http://www . ekologi. litbang.depkes.go.id/data/vol\%202/ Anwar2_1.pdf. (diakses 2 November 2009). 2003.

10.Anonim. Udang: Kaya Protein dan Rendah Kalori. Tersedia di http://www.sportindo.com/ page/181/Food_Nutrition/Articles_Tips/ Udang_Kaya_Protein_dan_Rendah_Kalori.html (diakses tanggal 2 Nonember 2008). 2007.

11.Linkages. Satu-satunya sumber cairan yang dibutuhkan bayi usia dini. Tersedia di: http:// www.linkagesproject.org/media/publications/ ENA-References /Indonesia/Ref4.7\%20.pdf. (diakses 2 November 2009). 2002. 